\title{
戦前広島における建築家活動の実態について
}

一地方都市における建築家活動の形態とその特徵に関する研究—

\section{THE STUDY ON THE ACTIVITIES AND THEIR FEATURES OF ARCHITECTS IN HIROSHIMA BEFORE WORLD WAR TWO}

- The study on the architects activity form and feature in local city-

\section{李 明*, 石丸 紀 興** \\ Li MING and Norioki ISHIMARU}

\begin{abstract}
This paper aims to explore the state of activities of architects in modern Hiroshima. Based on the sufficient understanding to modern architectures, their designers and designing organizations of pre-war Hiroshima, this study tends to clarify the features of the activities of those architects who were in Hiroshima during Taisho period and the earlier stage of Showa period. The results of this study are: Before being bombarded, the mainstream of architects' activities in Hiroshima was of those non-local architects, particularly, (1) activities of architects by utilizing Trust System in earlier stage of Showa; (2) building institutions of Guan Gong Sheng Ting and the activities of architects; (3) moreover, a series of bank buildings, with the involvement of famous architects, such as Kingo Tatsuno and Uheiji Nagano, and by their respective single piece of work, contribute a lot in the history of architecture of modern Hiroshima. In addition, up to now, little has been known about the activities of folk architects or non-government building institutions. And the pieces of work from local building institutions are few as well.
\end{abstract}

Keywords: Local city, Hiroshima, Modern Architecture, Architect, Activity form, Design style 地方都市、広島、近代建築、建築家、活動形態、デザイン様式

1. はじめに

本稿では、広島の近代建築を建築家の活動と関連させて考察する ことにより、戦前地方都市における建築家活動の形態とその特徽に ついて明らかにしょうとするものである。

都市を形成する建筑物は、建設される場との係わりが強いと言わ れている。従って環境財として優れた都市を建設し、建築を残すた めには、地域的条件が考慮される必要がある。ここで、まず地方を 対象に歴史的展開の中で、公共機関、民間による建設活動、あるい は建築家活動の特徴などの実態を明らかにすることが重要といえよ う。また、地方における建築家の活動は、これまでの日本の近代建 筑史研究の中であまり重視されてこなかった。しかし、実際には多 くの建築家の活動があり、そのような活動を含めた研究を進めなけ れば日本の近代建築史は曖昧なままで終始するだろう。本研究はこ のような状況に対応する研究の一助としても重要である。

広島は中国地方の中核都市として明治末期から多くのレンガ造、 コンクリート造の建物が建てられるようになった。その設計には、 日本を代表する建築家辰野金吾や長野宇平治なども関わり、多くの 有力な建築家が広島で活動を見せたのである。戦前の広島の建築は 被爆によって大部分が廃墟になり、建物に関する資料はほとんど散 逸し、また存続している建築は少ない。さらに、存続している被爆 建物は周囲の建物と共にそれなりの都市環境を創り出しているが、 現地では市街地再開発に当ってそれらに対する正確な情報を求めて
いる。ここで、広島の近代建築をその設計者と関連させて考察する ことは、広島の近代建築を把握する上で重要であるだけでなく、地 方における建築家活動を論じる上でも重要な意味を持つだろう。 広島の近代建築については、合衆国戦略爆擊調查団の報告書やや被 爆建造物調查研究会による調查記録ðがあり、また佐藤重夫らによる 原爆ドーム（広島県産業奖励館）に関寸る研究やや筆者による一連の 研究かがある。本稿ではこれらを適宜参考にしつつ、さらに諸文献と 調査を通じで広島における建築家活動の実態について論じたい。

\section{2. 戦前広島の近代建築の建設過程}

戦前、広島には建物としてどのようなものが存在していたのか、 それを解明するのは容易ではない。その際、被爆時存在した建物に ついては、合衆国戦略爆撃調查団の報告書「広島に対する原子爆弹 の効果」に載っている被爆建物リストによってほぼ把握できる。報 告書によれば、調査対象になったのは、135 件の建物であった。し かしこれらの調査団の被爆建物リストにはいくつかの建物名の間違 いが見られか、また、この 135 件の中に含まれていない建物がさらに 存在するということである。。現存する建物は確認補充することがで きるが、被爆前に取り壊された建物や被爆時に消滅したり、その後 に取り壊されたりした建物すべてを、現段階で把握することは困難 である。ここで、本稿では合衆国戦略爆慗調查団の調查対象になっ た 135 件の建物を主な考察対象にし、諸文献調査を通じて若干の確

\footnotetext{
$*$ 広島国際大学建築創造学科 講師 ・博士 (工学)

** 広島国際大学建築創造学科 教授.工博
}

Lecturer, Department of Integrated Architecture, Hiroshima International University, Dr. Eng.

Prof., Department of Integrated Architecture, Hiroshima International University, Dr. Eng. 
認と補足を試みながら、広島の近代建築について考察する。

\section{$2-1$. 軍用建築}

広島市において、従来にない大規模な非木造建物が建設されるよ うになるのは、明治以降の軍都化の過程、いいかえるなら軍に関連 した施設の整備過程においてである。軍事施設、軍用建物は、基町 などの都市中心部から牛田、宇品、出汐、霞 (現在の地名) といった 都市周辺部に及んでおり、各地区においいて大規模な建物が建てられ た。明治 4 年の軍制改革によって鎮西鎮台の第 1 分営が広島城を本 拠に設置された 11 年には第 5 師団と改称され、いくつかの連隊が配置された。それ に伴い、明治 10 年代末から 30 年代初にかけて基町地区にレンガ造 による倉庫等も建設されたと考えられる。日清戦争の際、広島は臨 時首都の様相を呈し、基町の西練兵場内に設けられた仮議事堂では、 第 7 回臨時帝国議会（明治 27 年 10 月 15 日）が開催された。その議 事堂は木造であるが当時内務省 3 等技師妻木頼黄による設計であつ た”。明治 27 年の日清戦争は、10 年後の日露戦争とともに広岛市に 軍事施設の集積を強いることとなったと言えるだろう。

軍事施設そのものではないが、牛田水源地は広島軍用水道として 陸軍の直轄工事で施工された。日清戦争終結直後の明治 28 年 11 月 に公布された臨時広島軍用水道布設部官制 ににより陸軍の直轄工事 として計画、明治 29 年 5 月から工事が始められ、2 年後の明治 31 年 8 月に完成しため。その風景は明治 31 年 8 月 25 日通水式の写真か ら確認できる゙。の後数期にわたって应張・整備が施されていった。 大正 13 年の 3 月に取水ポンプ室がレンガ造で、 5 月に送水ポンプ室 が鉄筋コンクリート造レンガ張りで、また緩速滤過池の上屋として 楕円形のドームを载せた 7 基の附属建物がレンガ造で整備された。 これらは軍事施設というよりむしろ都市施設に属するが、いずれに せよ水道事業がレンガの製造とレンガ造の建設を著しく促進させた といえよう。当初基町にあった広岛陸軍兵器支廠を東新開(霞)に移 転させるため、明治 37 年 1 月からレンガ造 2 階建てと木造によって 兵器の格納倉庫群や修理工場群が建ちはじめ、大正期にいたるまで 続々と姿を現し、大正 7 年には一大兵站基地が形成された（昭和 15 年に兵器補給廠と改称)。明治 44 年 3 月には宇品陸軍糧秣支厰の缶 詰工場が宇品御幸通りに鉄骨造と連続一体化した巨大なレンガ造で 建設された。また明治 38 年 9 月に撮影された出汐の陸軍被服廠広 岛派出所の建設は、大規模な木造建築であるが、更にそれに続いて 建てられ大正 2 年 8 月に完成した 4 棟の倉庫は、鉄筋コンクリート 造にレンガ積みを混用した巨大な建物であったことは特筆される。 このように明治中期から大正初期にかけて多くの巨大なレンガ造軍 事施設が広島に出現した。広島の藩政時代からの脱皮を告げる建物 はまず、軍事建築の大規模建築、特にレンガ造建築からはじまった と言ってもよいであろう。軍用建築は生産・保管・管理などの産業 的な機能とともに、とりわけ強固で耐久・耐火的な性能が要求され る場合があり、そのような建物は従来の日本建築では充足されず、 イギリスの影響もあってレンガ造が普及していったのであるす。

以上のように、軍都として多数の陸軍の関連施設が都心、郊外に 建設された。これらの軍関係建築の設計には多くの建築家・設計組 織の活動が推測されるが、これまで確認できるのは陸軍経理部（昭 和 15 年竣工の広島陸軍幼年学校を設計）のみである。諸文献資料 円により確認できる軍関係建物をまとめると表 1 のようになる。
表 1 軍関係の建物

\begin{tabular}{|c|c|c|c|}
\hline 建物名称 & 竣工年 & 設椋者/施工者 & 槽造 \\
\hline 広息仮部事堂 & 明贻27年 & 孃木頼黄 & 木造 \\
\hline 牛田水源地ポンプ室·海関室 & 明治31年 & 不咩 & レンガ造 \\
\hline 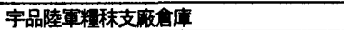 & 明治43年 & 不咩 & レンガ造 \\
\hline 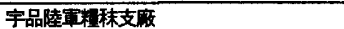 & 明治44年 & 不詳/大林組 & レンガ・鉄骨造 \\
\hline 広貫㓐軍被服支廠 & 大正2 年 & 不靽 & RC-レンカ張り \\
\hline 広息陸軍兵器補給晟 & 大正9年 & 不辞/大岩組 & レンガ造 \\
\hline 牛田水源地清過池調整機上屋 & 大正 13年 & 不群 & レンガ造 \\
\hline 牛田水源地送水ポンプ室 & 大正 13年 & 不咩 & RC造 \\
\hline 牛田水源地昜水室 & 昭和 10年 & 不輁 & RC造 \\
\hline 宇品瀵旋领 & 昭和14 年 & 不詳/笛水組 & $\mathrm{RC}$ 造 \\
\hline 広禺陸軍幼年学校 & 昭和 15 年 & 陵荲释理部不詳 & RC造 \\
\hline 中国軍管区関連施設・供給品臨時集積所 & 不群 & 不咩 & レンガ造 \\
\hline 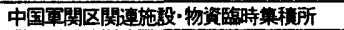 & 不群 & 不辞 & レンガ造 \\
\hline 中国軍管区関戛施数-兵器部會库 & 不僐 & 不群 & レンガ造 \\
\hline 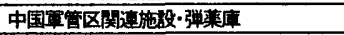 & 不群 & 不群 & $R C$ 造 \\
\hline
\end{tabular}

注：表 1 は、注 17）に示している参考文献を参照に箨者が作成した。

2-2. 金跲関係・文教建築

広島におけ括近代建築は、軍用建物がレンガ造で建てられたのに引 き続き、金融建物や産業建物においてレンガ造が建設され、さらに 大正期になると民間・公共建物において鉄筋コンクリート造が続々 と建てられる。ここでは金融関係建築と文教建築について述べる。 ここで、諸文献资料 ${ }^{18)}$ により確認できる、金融関係建築をまとめ ると表 2 に、文教関連建築をまとめると表 3 になる。

表 2 のように、レンガ造としては、まず明治 32 年に住友銀行広島 支店が建設されていたことが注目される。次いで第六十六銀行京橋 出張所 (明治 33 年)、広島県農工銀行 (明治 39 年)、広島商業銀行 本店（大正 2 年）、不動貯金銀行広島支店（大正 5 年）、西村好時の 設計による農林中央銀行広岛支店 (大正 9 年)、住友合資会社工作部 の設計による住友銀行広島支店東出張所(大正 10 年)、などが続く。 なお、鉄筋コンクリート造の金融関倸建物は、大正 10 年の安田生命 広島支店、続いて渡辺節の設計による鴻池銀行 (大正 12 年)、長野宇 平治の設計による三井銀行広岛支店（大正 14 年）、建築興業の設計 による日本証券取引所広島支所 (昭和 1 年) と芸傭銀行 (昭和 2 年)、 宗兵蔵の設計による千代田生命 (昭和 3 年)、竹腰健造の設計による 住友銀行 (昭和 3 年)、桜井小太郎の設計による明治生命 (昭和 4 年)、 增田清の設計による広島県農工銀行本店（昭和 6 年）といったとこ ろが続く。表 3 のように、文教建築は、岡田信一郎の設計による浅 野図書館（大正 15 年）、文部省営繥課の設計による広島高等学校講 堂 (昭和 2 年)、増田清の設計の本川国民学校 (昭和 3 年)、文部大臣 官房建築課の設計による広島文理科大学本館 (昭和 6 年)、広島県営 繕課の設計による県立広島商業学校（昭和 9 年）など建てられた。

以上のように、昭和 10 年頃まで多くの鉄筋コンクリート造による 建物が広島に建設された。このような非木造化、とりわけ鉄筋コン クリート化を促進する動きは、関東大震災を背景にしながら、その 他の理由も作用した。大正 14 年 4 月 10 日付中国新聞に「公共建物 は成るべく鉄筋コンクリートで構造の強固期せ、郡市長警察署長へ の通牒」という見出しの記事に表れているように、公共建築の鉄筋 コンクリート構造化への誘導が、政策的に展開されたのである。そ こでは木造建物の構造的欠陥に触れ「成るべく鉄筋コンクリート造 りとする」よう促したのである。また木造の白蟻被害が挙げられる。 特に昭和初期に小学校での被害が多く報告されている。昭和 4 年 6 月 15 日付中国新聞に「小中学校を白蟻が一斉に熟う、広島市内の旧 校舎全部、県下各地にも被害甚大」という見出しで小学校の白蟻被 害について報じ、続いて同月 16 日中国新聞でも白蟻被害から鉄筋コ ンクリート化への方向について報じている。 
表 2 金融関係建物

\begin{tabular}{|c|c|c|c|}
\hline 建物名称 & 瑤工年 & 設椋者/施工者 & 搆造 \\
\hline 住友銀行広島支店(旧) & 明治32年 & 不咩 /大湘組 & レンガ造 \\
\hline 第六十六銀行京橋出張所 & 明治33 年 & 不群 & レンガ造 \\
\hline 日本銀行広自出張所 & 明治38 年 & 唇野金害/不羘 & 慥 \\
\hline 広里県農工銀行 & 明治39 年 & 不鲜 & レンガ造 \\
\hline 広鸼商羓銀行本店 & 大正2年 & 不詳 & レンカ造 \\
\hline 不蚛斯金銀行広贯支店 & 大正5年 & 不咩/藤田組 & レンカ造 \\
\hline 農林中央金庫広悤支所 & 大正9年 & 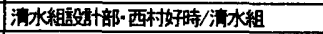 & Lンガ造 \\
\hline 住友銀行広岛支店東出張所 & 大正10年 & 住友合買会社工作部、大林組 & レンガ造 \\
\hline 安田生命広息支店 & 大正10年 & 不羘 /海水組 & $\mathrm{RC}$ 造 \\
\hline 濖池銀行広悤支店 & 大正11年 & 渡辺篮/不辞 & $\mathrm{RC}$ 造 \\
\hline 安田銀行広島支店 & 大正11年 & 不缮 & レンカ造 \\
\hline 三井銀行広島支店 & 大正14年 & 舞野宇平治/大會土木 & $\mathrm{RC}$ 造 \\
\hline 芸借銀行本店 & 昭和2年 & 建築興業/大林組 & $\mathrm{RC}$ 造 \\
\hline 千代田生命広焉支店 & 昭和 3 年 & 宗兵 藏/大全土木 & $\mathrm{RC}$ 造 \\
\hline 住友銀行厷舟支店(新) & 略和3 年 & 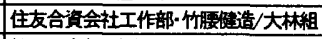 & RC造 \\
\hline 明治生命広島支店 & 昭和 4年 & 接形小太朗/清水組 & $\mathrm{RC}$ 造 \\
\hline 野村䟚券広息出張所 & 昭和 4年 & 不詳 & $R C$ 造 \\
\hline 三和銀行広酉支店 & 昭和4年 & 不群 & $\mathrm{RC}$ 造 \\
\hline 広再県農工銀行本店 & 昭和6 年 & 增田淟 /竹中工務店 & $\mathrm{RC}$ 造 \\
\hline 広陵信用組合本部 & 昭和6 年 & 大崎建築工陊所/不詳 & $\mathrm{RC}$ 造 \\
\hline 広禹銀行集合所 & 昭和10 年 & 竹中工務店/同左 & $\mathrm{RC}$ 造 \\
\hline 日本銀行広島支店 & 昭和11年 & 長野宇平治/海水組 & $\mathrm{RC}$ 造 \\
\hline 広蜜詝金支局 & 昭和12年 & 遄信省·山田守/藤田組 & $\mathrm{RC}$ 造 \\
\hline 三井物産広息出張所 & 昭和 12 年 & 不咩/㴋水組 & RC造 \\
\hline 三檴信用組合本部 & 昭和13年 & 海水組 /淟水組 & RC造 \\
\hline
\end{tabular}

注 : 表 2 は、注 18）に示している参考文献を参照に筆者が作成した。

表 3 文教建築のリスト

\begin{tabular}{|c|c|c|c|}
\hline 建物名称 & 䡛工年 & 設計者/施工者 & 桡造 \\
\hline 天満国民学校請堂 & 大正 13年 & 不鲜 & S 造 \\
\hline 光道国民学校 & 大正 13年 & 不鲜/藤田組 & $\mathrm{RC}$ 造 \\
\hline 広悤文理科大学永德閐(尚志会) & 大正 4 年 & 広島県立職業学校/同左 & レンガ造 \\
\hline 市立浅野图吾館 & 大正 15 年 & 岡田售一郎/竹中工務店 & RC 造 \\
\hline 藄德中学校武道場 & 大正 15 年 & 不鮮 & S造 \\
\hline 広我高等学校鿁堂 & 昭和 2 年 & 文部省虽縹棵 /不群 & RC 造 \\
\hline 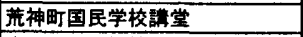 & 昭和 2 年 & 不群 & s 造 \\
\hline 本川国民学校校萻 & 昭和 3 年 & 增田 滰 /清水組 & RC 造 \\
\hline 広禹流川教会 & 昭和 2 年 & W·ヴォーリズ・内藤多仲/藤田組 & $\mathrm{RC}$ 造 \\
\hline 厷島工菜尃門学校発醉英験窒 & \begin{tabular}{|l|} 
昭和 4 年 \\
\end{tabular} & 不样 & RC 造 \\
\hline 千田国民学校陆堂 & 昭和 4 年 & 不咩 & S 造 \\
\hline 竹屋国民学校醮堂 & 昭和 4 年 & 不詳 & $S$ 造 \\
\hline 広自文理科大学本簛 & 昭和 6 年 & 文部少大臣官房建築課/大倉土木 & RC 造 \\
\hline 三籍国民学校讙堂 & 昭和 7 年 & 不样/清水組 & $S$ 造 \\
\hline 第一国民学校 & 昭和 7 年 & 不样/清水組 & $\mathrm{RC}$ 造 \\
\hline 褁立広身第二中学校铞堂 & 昭和 7 年 & 不样 /内外建築工務店 & $\mathrm{RC}$ 造 \\
\hline 本川国民学校講堂 & 昭和 8 年 & 不鮮 & S 造 \\
\hline 県立広睓第二中学校プール & 昭和 8 年 & 不群/生徒/教職員ら & $\mathrm{RC}$ 造 \\
\hline 昰立広禹商萧学校 & \begin{tabular}{|l|} 
昭和 9 年 \\
\end{tabular} & 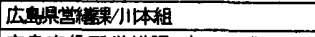 & $\mathrm{RC}$ 造 \\
\hline 袋町国民学校 & 昭和 12 年 & 厷身市役所棠綪锞/森田工業 & $\mathrm{RC}$ 造 \\
\hline 舟入国民学校俨堂 & 昭和 12 年 & 不群 & S 造 \\
\hline 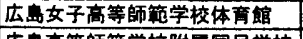 & 昭和 12 年 & 不样 & RC 造 \\
\hline 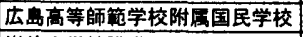 & 昭和 13 年 & 不群 & $\mathrm{RC}$ 遭 \\
\hline 甞德中学校鿁堂 & 昭和 13 年 & 不群 & $\mathrm{RC}$ 造 \\
\hline 官立厷岛市服学校䜊堂·職買室 & 昭和 16 年 & 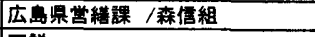 & $\mathrm{RC}$ 造 \\
\hline 広島市立中学校謐堂 & 昭和 18 年 & 不鮮 & S 造 \\
\hline 山陽中学校讙堂 & 不解 & 不群 & S 造 \\
\hline
\end{tabular}

注 : 表 3 は、注 18）に示している参考文献を参照に筆者が作成した。

\section{$2-3$. 産業建筮}

軍都化も産業的な性格をもつことは既に指摘したが、近代産業施 設そのものに触れてみよう。広島が細々とした地場産業から近代産 業都市へと蓄積をはじめるのは、まず紡績関係 ${ }^{19)}$ であり、大阪合同 紡績 (中国紡績を吸収)、日本麻紡績、帝人広島工場、金華人綟広島 工場等の企業が進出あるいは事業桩大する。そして産業的な発展を するためにも電力やガスといったエネルギー供給、電車やバスなど の交通機関が必要となってくる。さらに缶詰業、金属工業、化学工 業、造船業といった産業が次第に発達していく ${ }^{20)}$ 。多くの場合、そ ういった過程を非木造建物が支えていたのである。

ここで、諸文献資料 ${ }^{21}$ により確認できる産業建築とその他関連建 築をまとめると表 4 のようになる。表 4 のように、レンガ造で建設 された主な近代産業施設を、年を追って列挙すると、広島電燈火力 発電所 (明治 27 年)、中国紡績 (明治 29 年)、広島瓦斯広島工場 (明治 39 年)、広島電気軌道火力発電所 (大正元年)、日本麻紡績 (大正 8
年)、帝国人造絹広島工場(大正 10 年)などが挙げられる ${ }^{22}$ 。なお明 治 41 年に竣工した広島電燈亀山水力発電所は、水力発電を効率よく

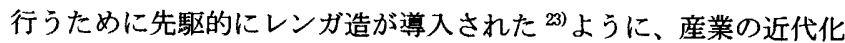
がレンガ建築を必要としたのである。レンガ造に次いで、鉄筋コン クリート造や鉄骨構造に展開していった。チェコ人ヤン・レッルが 設計した広島県物産陳列館(大正 4 年)、建築興業の設計による中国 新聞社本館 (昭和元年)、今井謙次・内藤多仲の設計による広島中央 放送局原放送所（昭和 3 年）、十代田三郎・内藤多仲の設計による広 島中央放送局（昭和 3 年）、増田清の設計による広島市役所（昭和 3 年）や燃料会館（昭和 4 年）、井戸田建築事務所の設計による麒麟麦 酒広島工場（昭和 13 年）などが鉄筋コンクリート造あるいは鉄骨造 との混合構造で建設された。また违信省の建築として、上浪朗の設 計による広島西電話分室（昭和 3 年）と広島违信局（昭和 8 年）や 山田守の設計による電気試験所広島出張所と広島中央電話局西分局 (昭和 12 年) などが建設される。なお、昭和 4 年に広島初の百貨店 として福屋百貨店が建設され、昭和 13 年には 8 階建ての新館が誕生 する ${ }^{24)}$ 。設計は片岡石本建築事務所と渡辺仁工務店がそれぞれ担当 したのである。昭和 9 年には金華人絹広島工場 (横川工務所の設計)、 昭和 11 年には広島富国館 ${ }^{25}$ （松尾光博建築事務所の設計）、昭和 14 年には佐藤功一の設計による赤十字社広島病院が建てられる。

表 4 産業·行政·商業及びその他建築のリスト

\begin{tabular}{|c|c|c|c|}
\hline 建物名称 & 竣工年 & 設㖕者/施工者 & 權造 \\
\hline 厷舟電燈火力発電所 & 明治 27 年 & 不群 & レンガ \\
\hline 中国紡繶 & 明治 29 年 & 不群 & レンガ \\
\hline 広岛瓦斯広舅工㘿 & 明治 39 年 & 不样 & レンガ \\
\hline 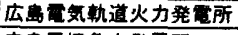 & 大正元年 & 不样 & レンガ \\
\hline 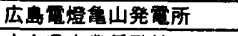 & 大正元年 & 不样 & レンガ \\
\hline 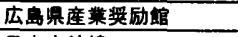 & 大正 4 年 & やン・レツル/椋田組 & RC 造 \\
\hline 日本麻紀繦 & 大正 8 年 & 不群 & レンガ \\
\hline 中国製紙 & 大正 9 年 & 不样 & $\mathrm{RC}$ 造 \\
\hline 広島地方專孛局 & 大正 10 年 & 不样 & $R C$ 造 \\
\hline 帝国人造螎広島工场 & 大正 10 年 & 不样 & レンガ造 \\
\hline 厷鶇駅 & 大正 11年 & 鉄道省 & $\mathrm{RC}$ 造 \\
\hline 日本十字社広盘支部 & 大正 14 年 & 不詳 & $R C$ 造 \\
\hline 中国新问社本館 & 昭和 1 年 & 建築興業·大森喜一/森田組 & RC 造 \\
\hline 厷禹中央電話局 & 昭和 3 年 & 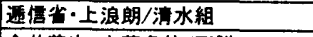 & RC 造 \\
\hline 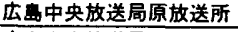 & 昭和 3 年 & 今井莱次·内藤多伸/不詳 & $\mathrm{RC}$ 造 \\
\hline 広島中央放送局 & 昭和 3 年 & 十代田三郎·内藤多仲/安藤組 & $\mathrm{RC}$ 造 \\
\hline 広意市役所 & 昭和 3 年 & 嘈田 清/渭池組 & $\mathrm{RC}$ 造 \\
\hline 然料会昆 & 昭和 4 年 & 增田 潗/清水組 & RC 造 \\
\hline 福屋旧館 & 昭和 4 年 & 片岡石本建筮事務所/竹中工務店 & RC 造 \\
\hline 広盘遁倍局 & 昭和 8 年 & 通售省·上浪朗/藤田組 & RC 造 \\
\hline 広鶇地方芰象台 & 昭和 9 年 & 広島罢党維課/不詳 & $\mathrm{RC}$ 造 \\
\hline 山陵文德殿 & 昭和 9 年 & 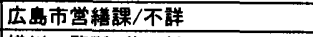 & RC 造 \\
\hline 金華人絧広島工場 & 昭和 9 年 & 横川工務所/藤田組 & $R C$ 造 \\
\hline 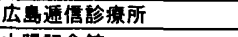 & 昭和 10 年 & 聥偠省·山田 守/坂本組 & RC 造 \\
\hline 山陆喆念馆 & 昭和 10年 & 佐藤功一/藤田組 & $\mathrm{RC}$ 造 \\
\hline 広島富国館 & 昭和 11年 & 松尾光搏建築事務所/海水組 & $\mathrm{RC}$ 造 \\
\hline 文試験所広岛出張所 & 昭和 12 年 & 击停省·山田守/不詳 & RC 造 \\
\hline 広舟中央電話局西分局 & 昭和 12 年 & 通傮省·山田守/藤田組 & RC 造 \\
\hline 福尿百少店 & 昭和 13 年 & 遮辺 仁/藤田組 & SRC 造 \\
\hline 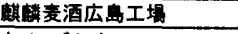 & 昭和 13 年 & 井戸田建築事務所/大會士木 & RC 造 \\
\hline キリンビヤホール & 昭和 13 年 & 井戸田建案事務所/清水組 & $R C$ 造 \\
\hline 広島赤十字病院 & 昭和 14 年 & 佐藤功一/藤田組 & RC 造 \\
\hline
\end{tabular}

注 : 表4は、注21）に示している参考文献を参照に筆者が作成した。

\section{3. 建築家活動の類型}

以上のように、広島における非木造建物は、軍用建築がレンガ造 で建てられたのに引き続き、民間商業建物や産業建物においてレン ガ造が建設され、さらに大正期になると民間・公共・学校建築にお いて鉄筋コンクリート造が続々と建てられる。こうして広島は近代 都市としての歩みを始め、大正、昭和初期ともなると広島の都心に もレンガ造、コンクリート造の大型の建物が多数建てられるように なる。これらは被爆に際しても倒壊しなかったものがあり、その建 
築的な特徵と建築家について確認することができる。前章で、その 設計者が確認できた建物（幾つかの木造建築を含める）を年代順に まとめると表 5 のようになる。

\section{表 5 戦前広岛での活動が確認できる建築家と作品}

\begin{tabular}{|c|c|c|c|c|}
\hline 竣工年 & 建物名称 & 建筑家·設吉十組樴 & 所屈 & 粗造 \\
\hline 明治 27 年 & 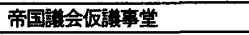 & 妻本頼黄 & $\mathrm{O}$ & 木造 \\
\hline 明治 31 年 & 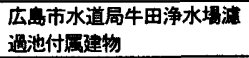 & WKパートン & 0 & レンガ造 \\
\hline 明治 38 年 & 日本銀行広國出張所 & 辰野金吾 & 0 & 木造 \\
\hline 明治 40 年 & 三十四銀行広禹支店 & 辰野金吾 & 0 & 慥 \\
\hline 大正 4年 & 広身絮物産陳列館 & ヤン・レツル & 0 & レンガ造 \\
\hline 大正 4年 & 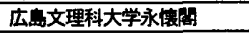 & 広禹紧立職工学校 & 9 & レンカ造 \\
\hline 大正 9 年 & 輹林中央金庫広息支所 & 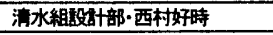 & $\mathrm{O}$ & レンカ造 \\
\hline 大正 10 年 & 住友銀行東松原支店 & 住友合识会社工作部 & $\mathrm{O}$ & レンカ造 \\
\hline 大正 11 年 & 広虫职 & 釷道省経理局 & 0 & $\mathrm{RC}$ 造 \\
\hline 大正 12 年 & 清池鋇行広息支店 & 渡辺管 & $\mathrm{O}$ & RC造 \\
\hline 大正 14 年 & 三井鍶行広息支店 & 晨野宇平治 & $\mathrm{O}$ & $\mathrm{RC}$ 造 \\
\hline 昭和 1 年 & 日本正券取引所広息支所 & 砫築興粪 & $\mathrm{O}$ & S.RC進 \\
\hline 昭和 1 年 & 中国持文社本领 & 建筑興㶳·大菻量一 & 0 & RC造 \\
\hline 昭和 1 年 & 市立滰野图䗆 & 岡田传一郎 & 0 & $\mathrm{RC}$ 造 \\
\hline 昭和 2 年 & 広禹高管掌挍数堂 & 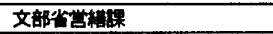 & 0 & $R C$ 造 \\
\hline 昭和 2 年 & 芸侻銀行本店 & 兡築與策 & 0 & $\mathrm{RC}$ 造 \\
\hline 昭和 2 年 & 広㿼流川教会 & W・ヴォーリズ・内藤多仲 & 0 & $\mathrm{RC}$ 造 \\
\hline 昭和 3 年 & 広島中央放送局原放送所 & 今井莱次·内藤多仲 & 0 & $\mathrm{RC}$ 造 \\
\hline 昭和 3 年 & 広島中央䣶局 & 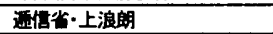 & 0 & $\mathrm{RC}$ 造 \\
\hline 昭和 3 年 & 広禹市役所 & 翼田清 & 0 & $\mathrm{AC}$ 造 \\
\hline 昭和 3 年 & 広島中央放送局 & 十代田三郎-内藤务忡 & 0 & $\mathrm{RC}$ 造 \\
\hline 昭和 3 年 & 本川国民学校校萻 & 增田清 & 0 & $\mathrm{RC}$ 造 \\
\hline 昭和 3 年 & 千帒田生的広島支社 & 宗兵藏 & 0 & $\mathrm{RC}$ 造 \\
\hline 昭和 3 年 & 住友銀行厷㤩支店 & 住友合资会社工作部·竹腾俔造 & 0 & $\mathrm{RC}$ 造 \\
\hline 昭和 4 年 & 蛻料会䗆 & 徣田清 & $\mathrm{O}$ & $R C$ 造 \\
\hline 昭和 4 年 & 明治生命広自支店 & 揬井小太郎 & 0 & $\mathrm{RC}$ 造 \\
\hline 昭和 4 年 & 福屋旧寉 & 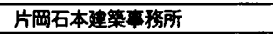 & 0 & $\mathrm{RC}$ 造 \\
\hline 昭和 4 年 & 中国䂗店 & 權本建策事務所 & 0 & $\mathrm{RC}$ 造 \\
\hline 昭和 6 年 & 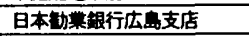 & 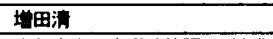 & 0 & $\mathrm{RC}$ 造 \\
\hline 昭和 6 年 & 広禹文理科大学本倌 & 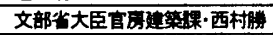 & 0 & $\mathrm{RC}$ 造 \\
\hline 昭和 6 年 & 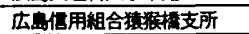 & 大海建筑工税所 & 0 & $\mathrm{RC}$ 造 \\
\hline 昭和 8 年 & 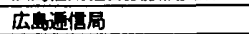 & 通售省·上浪朗 & 0 & $\mathrm{RC}$ 造 \\
\hline 昭和 9 年 & 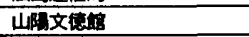 & 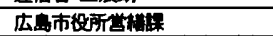 & 0 & $\mathrm{RC}$ 造 \\
\hline 昭和 9 年 & 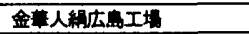 & 樍川工務厥 & 0 & $\mathrm{PC}$ 造 \\
\hline 昭和 9 年 & 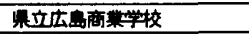 & 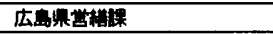 & e & $\mathrm{RC}$ 造 \\
\hline 昭和 9 年 & 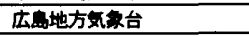 & 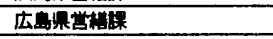 & 0 & $\mathrm{RC}$ 造 \\
\hline 昭和 10 年 & 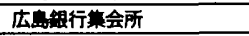 & 竹中工陊店 & 0 & $\mathrm{RC}$ 造 \\
\hline 昭和 10年 & 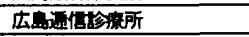 & 逼牦省-山田守 & 0 & $\mathrm{RC}$ 造 \\
\hline 昭和 10年 & 山陆地念馆 & 佐䕨功一 & 0 & $\mathrm{PC}$ 造 \\
\hline 昭和 11 年 & 広息員商工経清会 & 今井兼次-小田能浀 & 0 & $\mathrm{RC}$ 造 \\
\hline 昭和 11 年 & 去量豆国馆 & 松层光榑建策事務所 & 0 & RC造 \\
\hline 昭和 11 年 & 日本銀行広禹支店 & 長野宇平治 & 0 & $\mathrm{RC}$ 造 \\
\hline 昭和 12 年 & 等町国民学校 & 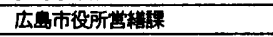 & 0 & RC遗 \\
\hline 昭和 12 年 & 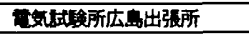 & 通借省-山田守 & 0 & $\mathrm{RC}$ 造 \\
\hline 昭和 12 年 & 広島貯金支局 & 茞信省一山田守 & 0 & $\mathrm{RC}$ 造 \\
\hline 昭和 12 年 & 広毒中央電䄆局西分局 & 粪儅省-山田守 & 0 & RC造 \\
\hline 昭和 13 年 & 福整百货店 & 渡暹仁 & 0 & $\mathrm{RC}$ 造 \\
\hline 昭和 13 年 & 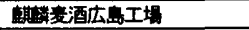 & 井戸田建築事務所 & 0 & $\mathrm{RC}$ 造 \\
\hline 昭和 13 年 & キリンビヤホール & 井戸田建築事務所 & 0 & $R C$ 造 \\
\hline 昭和 13 年 & 厷贯市矰用組合本部 & 海水組 & 0 & $\mathrm{RC}$ 造 \\
\hline 昭和 14 年 & 赤十字社広里病院 & 佐藤功一 & 0 & RC造 \\
\hline 昭和 15 年 & 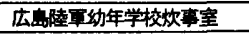 & 陸軍経理部 & 0 & $\mathrm{RC}$ 造 \\
\hline 昭和 16 年 & 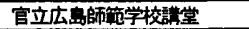 & 厷岛県裳楼課 & 0 & $R C$ 造 \\
\hline
\end{tabular}

注 : 記号○は外来建築家・設計組織を示し、は地元建築家・設計組織を示す。

表 5 をみると、設計者が確認できる建物は 53 棟である。その中、 広島の営䋨組織の設計が 6 棟であり、残り 47 棟は広島に㧋点を置か ない外来建築家・設計組織により設計されたことが指摘できる。ま ず、戦前の広島において活動した外来建築家及び設計組織をその活 動の拠点によって首都圈の建築家、関西及び所在不詳の建築家、国 の営繕組織の建築家、外国人建築家として 4 つに区分してまとめる と図1のようになる。このように、外来建築家の活動として、(1)東 京加以は辰野金吾、長野宇平治、西村好時、大森喜一、岡田信一郎、 今井兼次、内藤多仲、桜井小太郎 ${ }^{26)}$ 、佐藤功一、渡辺仁、建築興業、 横川工務所、清水組、井戸田建築事務所などの建築家又は設計組織 の活動、(2)関西加以渡辺節、増田清、宗兵蔵、竹腰健造、片岡石 本建築事務所、住友合資会社工作部（現日建設計）、竹中工務店とい う建築家又は設計組織の活動、(3)国の営䋧組織からは、宮内省の建
築家妻木頼黄、违信省の建築家山田守、上浪朗、十代田三郎 ${ }^{27)}$ 、文 部省大臣官房建築課の西村勝、なお鉄道省経理局、文部省営繕課、陸 軍経理部などの活動、(4)外国人建築家の活動としてW. K. バートン、 チェコ人建築家ヤン・レツル、W. ヴオーリズの活動、(5)その他、橋 本建築事務所、大崎建築工務所、松尾光博建築事務所の活動、など があったことが分かる。

なお、表 5 と図 1 を見ると民間建築家の作品として増田清、佐藤 功一の作品がいくつか見られて比較的目立つものの、その以外の建 築家の作品は殆ど単発的な作品になっていることが分かる。そして、 国の営緗組織の建築家の活動として山田守の作品が比較的に多かっ たことが注目されるのである。

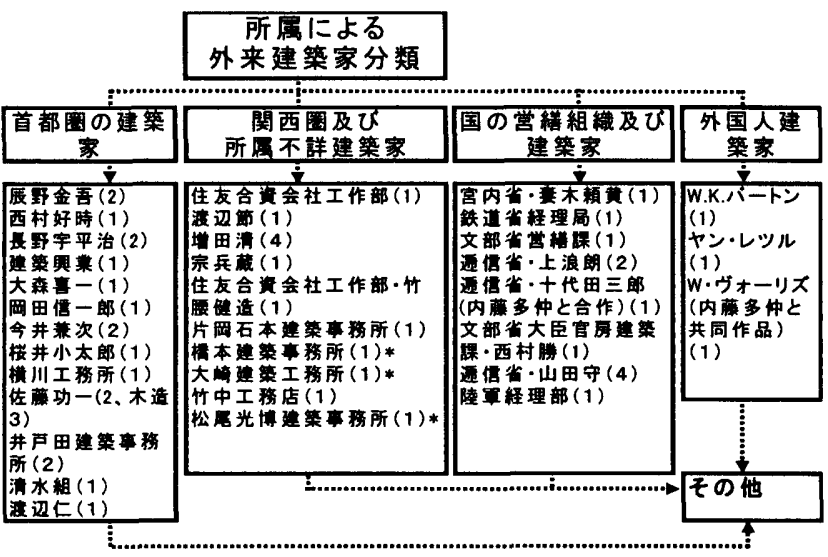

図 1 戦前広島における外来建築家活動の類型

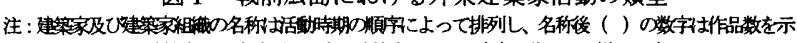

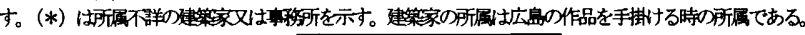

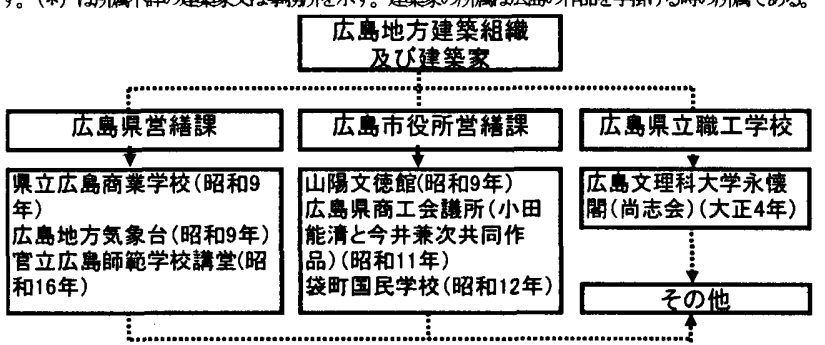

図 2 広島地方建築組織の活動類型

地元の建築家又は設計組織の活動について、今の段階で確認でき るものをまとめると図 2 のようになる。このように、地元建築家の 作品は見当たらない。広島の地方組織として広島県営絴課、広島市 役所営䋛課、広島県立職工学校の活動が見られるものの、その組織 における具体的な建築技師らについては不明である。唯一市役所営 䋨技師小田能清の作品として確認できるのが 1 棟あるが、それも東 京の今井兼次との協力作品であった。このように広島地元の建築家 の作品は未だ確認することができず、地方の営䋨組織の作品もかな り少なかったことがわかる。

以上のように、戦前広島における建築活動の主流を占めたのは外 来建築家であり、特に、辰野金吾、長野宇平治、佐藤功一、山田守 など、中央から広島に訪れて設計活動をした建築家の活動が注目さ れる。なお、広島の民間建築家又は建築事務所の活動は、現段階て は不明であり、地方営繥組織の作品も少なかったことが指摘できる。

\section{4. 外来建築家の活動とその特徴}

前章において、戦前広島の近代建築を語る上で外来建築家の活動 は非常に重要であることが明らかになった。ここでは、広島の近代 
建築における外来建築家の活動とその特徽について考察する。外来 建築家の活動は大きく国の営繥組織の建築家と民間建築家の活動に 大別することができる。

\section{4-1. 国の営䋨組織の建築家の活動}

国の営繥組織として、戦前広島における建築活動に関わったのは鉄 道省経理局、文部省営繥課、文部大臣官房建築課、违信省経理局営 繕課などである。官庁省の建築家の活動の役割については日本近代 建築史において多く特筆されている。ここで注目されるのは日本近 代機能主義·合理主義建築をリードした违信省の建築家の活動であ る。旧広島违信診療所（昭和 10 年）、旧広島貯金支局 (昭和 12 年)、 旧電気試験所広島出張所（昭和 12 年）、旧広島電話局西分局（昭和 12 年)、何れも山田守（1894～1966）の設計であった。特に、葿信 省の建築家として聥信省在任中数多くの局舎建築を設計した山田守 であるが、通常の局舎建築とは趣を異にする初の病院建築を広島に

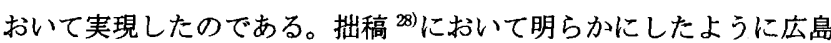
莪信診療所は、その規模は小さいが山田守にとっては最初の病院建 築設計として、その設計理念と手法は東京莪信病院という日本近代 合理主義代表作の設計に大きな影響を及ぼした建筑であり、後の東 京违信病院を初めとする数多くの大病院建築を設計する原点であっ た。このように山田守の初の合理主義建築は、一早くヨーロッパの 機能主義·合理主義を広島に紹介した役割を果したのである。なお、 旧広島违信局庁舎 (昭和 8 年) と旧広島郵便局電話分室 (昭和 3 年) は、莪信省の建築家上浪朗の設計であった。大正 15 年着工、昭和 3 年竣工の広島郵政局電話分室は、日字型の平面構成になり、中庭を 通して各室に入るなど、機能によって空間を配置する意匠を呈した。 正面ファサードは、連続する垂直線繰形の半柱や繸長空によって垂 直線を強調している。これらの設計手法は大正 14 年着工の横浜中央 電話局長者町分局建築にも表れている。また当時山田守らの表現派 風局舎には頂階の空にアーチ模様を繰り返すなどのデザインが多か ったが、上浪朗は広島郵政局電話分室において入口に放物線の曲線 を持ったアーチ模様のデザインを施すなど独自のデザインを追求し ていた。このようなアーチ模様の入口の設計は、昭和 3 年竣工の熊 本莪信局庁舎や昭和 4 年竣工の芦屋郵便局電話事務室の入り口にも 現れている。また芦屋郵便局電話事務室の 1 階の空に連続ア一チを デザインするなど、彼の折禹的な性格と個人の独自的な手法になっ ている。それらと比べて、昭和 8 年 3 月竣工の広島违信局舎は装飾 を一切付けず、外壁にはクリーム色のタイルを張り、大きい空が整 然に並らぶなどモダンな建築であった。このようなスタイルは当時 連信省経理局営縒課の潮流であったが、それをリードして来た吉田 鉄郎と山田守らの活動が、後輩である上浪朗らにも大きな影響を与 えたと思われる。広島聥信局の建築は後の山田守設計の広島莪信診 療所の建筑（昭和 10 年）に比べてやや重厚な感じを与えているが、 当時の広島においては極めてモダンな建築であった。

以上のように、日本の 30 年代合理主義建築をリードした逓信省の 建築家の活動は、地方都市の建築近代化においても先鋒的な役割を 果たしたのである。

\section{4-2. 民間建築家の活動}

民間建築家の活動形態を見ると嘱託による活動と建築主の依頼 やコンペによる単発的な設計活動の二つに分けることができる。

広島県や市の嘱託を受けながら活動を見せた建築家増田清 29) と佐

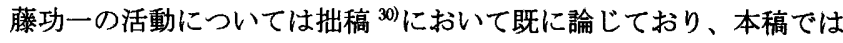
省く。そこで、本節では主に外来建築家の活動の特徴である単発的 な設計活動について論じる。大正、昭和初期ともなると広島の都心 にもレンガ造、コンクリート造の大型の建築物が多数建てられるよ うになるが、金融関係の建築物はステータスを示す意図が強く、豪 華な装飾をもつものが多い。またインテリアは大きな吹き抜けの営 業ホールを持つのを恒とし、他の種類の建築物とは一線を画する形 態を誇った。ここで、戦前広島の近代建築と建築家の活動を考察す るには一連の銀行建築に注目し、その設計者と関連して考察するこ とが有効であると考えられる。

1）辰野金吾と日本銀行広島出張所、三十四銀行広島支店 : 日本銀 行本店、東京駅などの名作品を残した日本を代表する建築家辰野金 吾 ${ }^{31)}(1854 \sim 1919)$ の作品が広島に2つ建てられた。一つは明治 38 年に建てられた日本銀行広島出張所 ${ }^{32}$ （写真 1）である。木造 2 階 建ての規模で、その外観にはイオニア式の付け柱が壁面に林立し、 半円形や三角形のペデイメントが要所に用いられており、玄関上の ドーム付近、空、屋根空の枠にバロック風の装飾が施されているな どの特徵を現している。もう一つは、明治 40 年に中島本町の東寄り の、伝統的な町家が並ぶ一角に建てられた三十四銀行広島支店であ る。間口が狭くて奧行が長い敷地一杯に、軒を接して建てられたこ の建物は、木造でありながら、ファサードのみに、レンガと石を交 互に積層するなどの装飾が施されている。このように辰野金吾は、 広島では木造建築に「辰野式」と呼ばれる彼独特の装飾モチーフを 示すにとどまった。なお、大正 2 年 12 月に建てられた広島商業銀行 本店（写真 2）は、交差点に面してアーチ状の玄関をとり、その上 に小さなドームを乗せる構成となっており、両サイドのレンガの赤 い壁面と白い御影石のデザインや屋根にドーマーヴインドーや換気 丸空がせめぎあっているなど、「辰野式」を思わせるが、その設計者 は不詳である。

2）第一銀行広島支店と西村好時 : 大正 4 年に広島に支店を開設し た第一銀行は、 5 年後の大正 9 年 5 月に大手町筋と本通りが交差す る角地に新築移転する。銀行建築の設計で名高い西村好時 ${ }^{33)}$ (1886 〜1961）が清水組設計部に在籍中に手掛けたものである。一部鉄箭 コンクリートを取り入れたレンガ造の 2 階建で、玄関は大手町筋側 と本通り側の 2 ヶ所に設けられ、内部の営業室は吹き抜けの大空間 となっていた。レンガ造の 2 層に渡る柱と、上部のアーチや装飾が 注目される(写真 3)。

3）千代田生命広島支社と宗兵藏：昭 3 年 8 月、金融機関が建ちな らぶ大手町筋に千代田生命広島支部の新社屋が竣工した。帝国奈良 博物館 (現在の奈良国立博物館)を手掛けた大阪の宗兵蔵 ${ }^{34)}$ (1864〜 1944）が設計。レンガ造 3 階建てのこの建物は、外壁の 1 階部分と上 層部に白い御影石が張られ、その間がレンガ壁で、赤と白がコント ラストをなす建物だった（写真4)。アーチ空、バルコニー、軒には ルネッサンス風の表現、小アーチの連続する軒蛇腹にはロマネスク の手法が取り入れられ、宗兵蔵の特徵を表す折衣様式で全体がまと められていた。

4) 三井銀行広島支店、日本銀行広島支店と長野宇平治 : 三井銀行 広島支店（写真 5、昭和 11 年竣工、現存）は、長野宇平治 ${ }^{35)}$ (1867 〜1937）が設計したのである ${ }^{36)}$ 。この建物は鉄筋コンクリート 2 階 建てで、敷地は南北方向に長く、現本通りに面している北側が正面 
となり、玄関が設けられている。正面玄関の両わきには、正面 2 酋 分の丸い石柱が左右おのおの 2 本ずつ建てられていた。1 階部には 中央の扉をはさんで 2 本ずつ、計 4 本のドリス式の柱頭を持つ石柱、 2 階部には 4 本のコリント式の柱頭を持つ石柱が設けられている。 東側の入口では、1 階部にのみ扉の両側に 1 本ずつ、 2 本のドリス 式柱頭を持つ石柱が設けられている。屋上のパラペット部は、いく つか正方形状に切抜き、そこに模様の入った木製の枠が嵌め込まれ

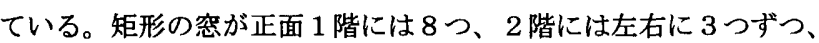
中央にアールのついた大きい空が 3 つ設けられ、バランスが良く整 えられている。外観は、1 階部分が横方向の目地の目立つ岡山産万 成岩 (花崗岩)、2 階部分は疑石ブロックとなっている。さらに、庇 はないが 1 階 2 階わずかに張り出した胴蛇腹を用い、細かな蛇腹模 様の装飾を施し、またパラペット部には、ブロッキング・コーニス （蛇腹押さえ）を用いて、階層毎にアクセントをつけ、水平線が強 調されている。このような装飾が用いられている点と、柱などがギ リシャの古典様式によって構成されている点は、西洋ルネッサンス 期にみられる構成美を追求する建築様式と思われる。日本銀行広島 支店（写真 6、現存）は、明治 38 年、辰野金吾が設計した木造洋風 建築の日本銀行広島出張所を、業務の拡大に伴い昭和 11 年 9 月新筑 移転したものである。その設計は日本銀行臨時建築部時代の長野宇 平治だった。この建物は、鉄筋コンクリート石張りの 3 階建てで、 昭和 11 年という時代背景もあってか、広島支店は東京日本橋の本店 のような華麗な装飾はなく、渦巻き状の柱頭を乗せた 4 本の角柱は イオニア式を採用し、シンプルな外観となっている。内部の営業室 には $1 ， 2$ 階を貫く大きな吹き抜けの大空間が設計られ、吹き抜け 空間には角柱が立つが、それにはより豪華なコリント式の柱頭飾り が施され、2 階の忍接室には大理石を使った豪華な装飾も見られた。

これらの長野宇平治の二つの作品は現存している。

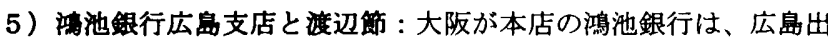
店に伴って大正 12 年 7 月、本通りのほほ中央部に支店を新筑した。 設計は日本勧業銀行本店など銀行建築を数多く手掛けていた渡辺節 37）（1884～1967）であった。この建物は、 $\mathrm{RC}$ 造の平屋・一部 2 階の 小規模なものだが、ルネッサンス様式を基本とし、正面の 3 連の飾 クアーチやコーナーストーン等が印象的な建物である（写真 7)。

6) 芸備銀行本店と建築興業 :『創業百年史』(広島銀行編 1979 年) によると、大正 9 年第六十六銀行や広島銀行など広島県内の有力 7 行が合併し、県下の最大手となる芸備銀行が発足した ${ }^{38)}$ 。大正 12 年初頭、市内紙屋町約 560 坪の土地を購入し、直ちに設計を東京の 建築興業に委託するが、関東大震災により設計図が焼失するという 事故があったため、改めて 13 年末から設計が再開され 14 年夏に完 成したという ${ }^{39)}$ 。その際、設計の要点は、(1)一目にしてこれは何の 建築であるかを誰もが知り得るように銀行らしい建物であること、 (2)機械設備之各室配置の関倸が合理的かつ機能的であること、(3)定の予算内において最大の効果を挙げること、(4)構造に無理がなく 耐震、耐火に万全を期すること、など 4 つの要素を完備することに あったという ${ }^{40}$ 。このうち耐震性への意識は大正 12 年の関東大震 災の影響が大きかったといえる。こうして芸備銀行（写真 8）は建 築興業の設計により、大正 14 年 8 月着工、昭和 2 年 6 月に竣工した。 建物は鉄筋コンクリート 5 階建て、地下 1 階の大規模なもので、外 観は近世復興式を採用し、正面の 2 階から 4 階にわたる大きなイオ
ニア式列柱、円形空やポイント的な装飾が特徵的である。これらの デザインは、「印象に残る銀行建築らしい美観」という設計要点の具 現と思われるが、「実用性」や「経済合理性」という側面は読み取り 難い。

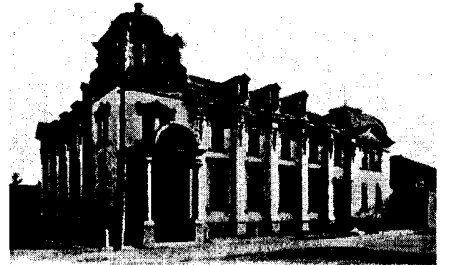

写真 1 日本銀行広島出張所

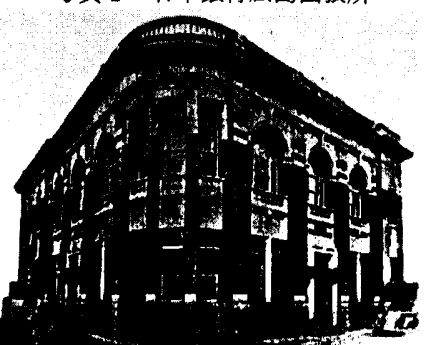

写真 3 第一銀行広島支店

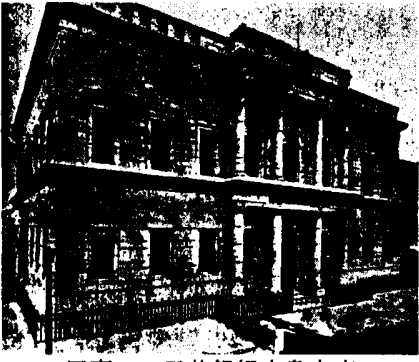

写真 5 三井銀行広島支店

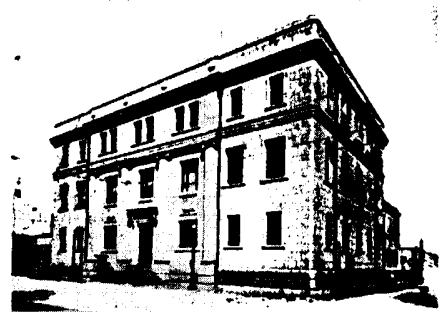

写真 6 日本銀行広島支店
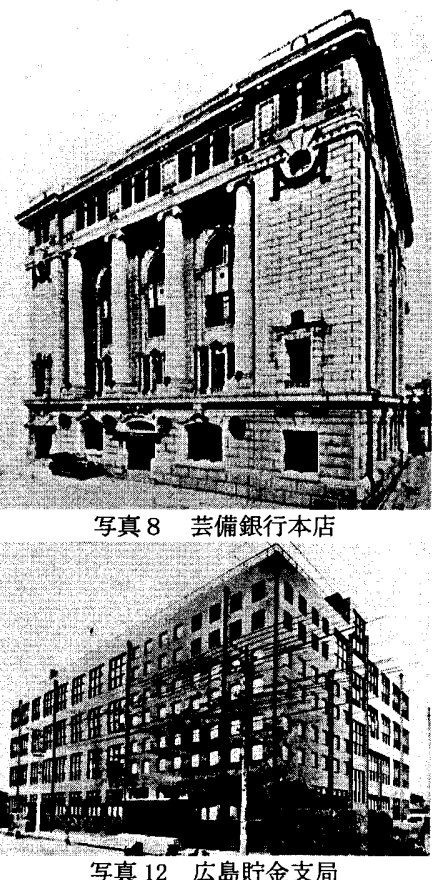

写真 12 広島貯金支局

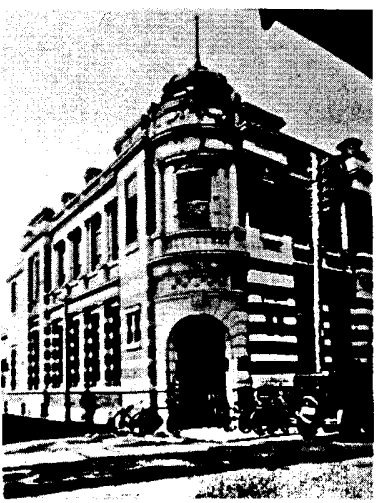

写真 2 広島商業銀行本店
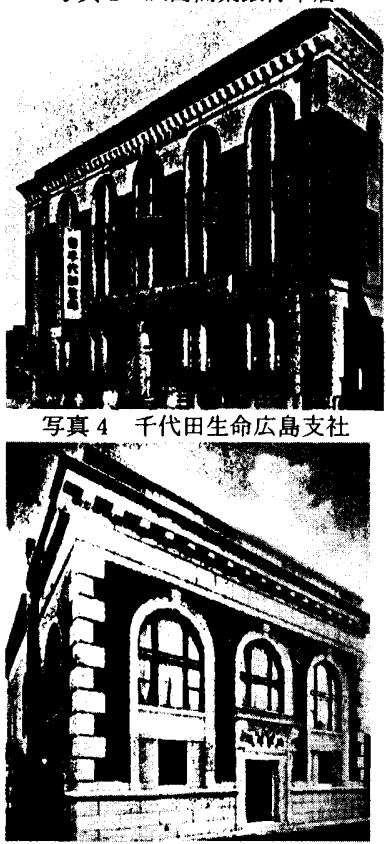

宣 7 鴻池銀行広島支店

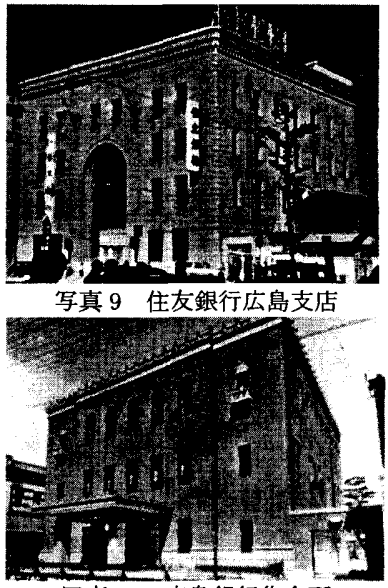

写真 10 広島銀行集会所

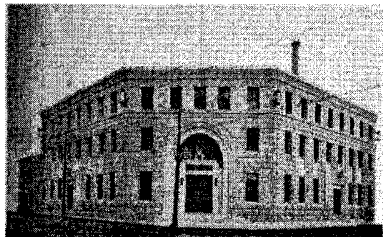

写真 11 広島県農工銀行本店 
7 ）住友銀行広島支店と竹腰健造 : 住友銀行広島支店（写真 9) は、 昭和 3 年 12 月紙屋町の交差点にほど近い電車通りに新築移転した。 鉄筋コンクリート 4 階建て、地下 1 階。昭和 2 年に竣工した芸備銀 行本店の南隣に位置し、幅と高さともほぼ同規模で建てられた。し かし、形態や様式では芸備銀行本店と異なり、対照的であった。設 計は住友合資会社工作部の竹腰健造 ${ }^{41)}$ であった。外観は平坦で閉鎖 的な壁面で囲まれ、正面中央部には繰型大アーチを設けている。装 飾は主にアーチの縁部と軒蛇腹部に施し、全体的にはロマネスク様 式で統一されている。内部は口の字型の平面で構成され、中央には トップライトのある 3 層に渡る吹き拔けの大空間が筒状に位置し、 営業室として利用された。銀行建筑としては珍しく正面に吹き抜け の営業室を採らない幾何学的な集中式空間となっていた。

8) 広島県農工銀行本店と增田清: 設計者は広島市役所の設計で広 島との関わりの深かった増田清で、建物は昭和 6 年 4 月に竣工した。 出入り口を交差点の角に向けてとる銀行建築の一典型のプランで、 外観は正面中央にアーチ状の入口を設け、1，2 階部分は横目地に よる積層的な構成とし、3 階部分には間壁にレリーフ装飾が付けら れていた。部分的な装飾は見られるものの全体的にはシンプルなデ ザインだった。増田は建築雑誌に「米国の銀行建築」という題でア メリカの銀行建築の専門家の意見を紹介しており、その際にこの銀 行の平面図を掲載している。この建物で增田はアメリカ式の合理的 銀行建築のあり方の具現を試みたのかも知れない（写真 11）。

以上のように、大正、昭和初期ともなると広島の都心にもレンガ 造、コンクリート造の大型の金融関倸の建物が建てられ始めた。金 融関係の建物の特徽は、ステータスを示す意図が強く、豪華な装飾 を持つものが多く、大きな吹き抜けの営業ホールを持つのを常とし た。それは建築興業の設計よって紙屋町に昭和 2 年に建った芸備銀 行本店に頂点を見せた。ヨーロッパの伝統的な古典主義的構成を正 確に示すものだが、都市空間を層によって秩序づけて表現するとい う日本人にはなじみの無かった立体構成の形式が、ここに広島にお いて大規模な形で提示されたのである。同様の古典主義的な構成は、 水平性を強調した軒のラインに沿わせて円柱を連続させた三井銀行 広島支店（大正 14 年）にも見られる。日本銀行時代の辰野金吾の弟 子に当たる長野宇平治が設計した三井銀行は、簡素ながらもオーダ 一装飾、アーチを挟んで矩形の空が並ぶ 3 連空の形式など、水準の 高い建築美学を示している。昭和 3 年には芸備銀行に並んで住友銀 行広島支店が登場する。住友合資会社工作部の竹腰健造が設計した 住友銀行は芸備銀行とほぼ同規模のフアサードを有するが、ここで はマッシブな石張りの壁面の中央部に巨大なロマネスク風半円ア一 チが設けられ、またアーチの縁や軒飾りには細かいアーチ形が連続 するロマネスク様式特有のモチーフが施され、単純で重厚な建築の 形式が示された。ルネッサンス様式のアーチは明治維新以来、洋風 建築の代名詞のようになっていたが、広島の本通りの中央部に現れ た渡辺節設計の鴻池銀行広島支店 (大正 12 年) は半円アーチを主モ チーフとした建築作品である。タイル張りの壁面とコントラストさ せた石のアーチは、中央上部に $V$ 字形の要石を挟み、アーチ間には 円形のメダル装飾を配し、建物の角は隅石飾りをつけ、軒蛇腹には 歯形装飾を並べるなど、そこにはコンパクトにルネッサンス様式装 飾が集約されていた。

1930 年代には徐々にそのデザインも変化して、建物は重厚さから
華やかさへと方向転換する。昭和 6 年には増田清が設計した広島県 農工銀行本店が建てられる。外観の正面中央にアーチ状の入口を設 け、1、2 階部分は横目地による積層的な構成とし、3 階部分には間 壁にレリーフ装飾が付けられているなど、部分的な装飾は見られる ものの全体的にはシンプルでモダンなデザインだった。それに比べ て昭和 10 年に建てられた広島銀行集会所（写真 10）の外観は全体 的にはシンプルながらルネッサンス風で構成されている。その設計 は竹中工務店であったが、建物の中央に 3 層にわたる吹抜けの上部 にトップライトを設けるなどュニックなデザインであった。昭和 11 年には長野宇平治が設計した日本銀行広島支店が建てられる。日本 銀行には華麗な装飾はなく、シンプルな外観となっているが、全国 の日本銀行支店と同じく古典主義の様式が採用されている。そして 登場するのが、违信省風の国際派スタイルで建てられた広島貯金支 局（昭和 12 年、写真 12）である。柱の間に目一杯の空を設けたこ の建物は、日本近代機能主義·合理主義建築をリードした通信省の建 築家山田守の設計であった。山田守は広島聥信診療所（昭和 10 年） の設計に続いて銀行建築においても国際派スタイルを広島に紹介し たのである。

以上のように、金融関係建築のデザインはやや様式主義的であっ たが、ヨーロッパの近代建築運動の影響を受けつつ、全般的な流れ としては近代主義的方向へと導かれたのである。

以上により銀行建築のデザインをまとめると表 6 のようになる。

表6 銀行建築のデザイン分析

\begin{tabular}{|c|c|c|c|c|c|}
\hline 建物名称 & 䡛工年 & 堅楮堵 & 筑造/盐数 & 柱式 & 道路亡の関系/スタイル特媎 \\
\hline 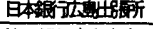 & 明治 38 年 & 辰里神金吾 & 慥/2陵 & イオ二ア式 & 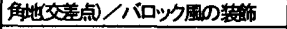 \\
\hline 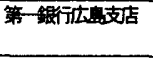 & 大正9年 & 西极姆持 & $\begin{array}{l}\text { レンガ造/3 } \\
\text { 陼 }\end{array}$ & 無 & $\begin{array}{l}\text { 触地(交着点)ノレンガの壁柱上軒部 } \\
\text { のア一千や装饰 }\end{array}$ \\
\hline 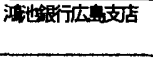 & 大正12年 & 掂双篮 & $\begin{array}{l}\text { RC造/平星: } \\
\text { 部階 } \\
\end{array}$ & 無 & $\begin{array}{l}\text { 街道み/3連のアーチ、ルネッサン } \\
\text { ス阵式 }\end{array}$ \\
\hline 三車鋸行庆笽支占 & 大正14年 & $\begin{array}{l}\text { 典野宇平 } \\
\text { 治 }\end{array}$ & RC造/2隌 & $\begin{array}{l}\text { ドーアアとコ } \\
\text { リト十式 }\end{array}$ & 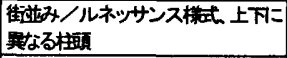 \\
\hline 芸潇銀行本店 & 昭和年 & 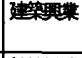 & $\begin{array}{l}\text { FC造/5階· } \\
\text { 地下1階 }\end{array}$ & 仏二ア式 & 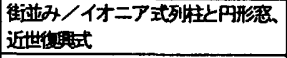 \\
\hline 住友根行庆鶇支店 & 昭和年 & 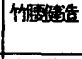 & $\begin{array}{l}\text { PC造/4陼· } \\
\text { 地下1階 } \\
\end{array}$ & 無 & 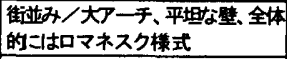 \\
\hline 千代丑生全広留支社 & 昭和年 & 宗究藏 & $\begin{array}{l}\mathrm{RC} \text { 造 } / 3 \text { 隌- } \\
\text { 地下1陼 }\end{array}$ & 無 & 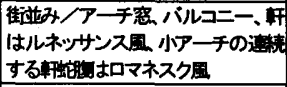 \\
\hline 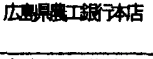 & 昭和年 & 䓵田棈 & $\begin{array}{l}\text { RC造/3階· } \\
\text { 地下1陵 }\end{array}$ & 無 & $\begin{array}{l}\text { 觔地(交着点)/ジプルデモダンな } \\
\text { デザイン }\end{array}$ \\
\hline 広牙銀行集会所 & 昭和10年 & $\begin{array}{l}\text { 竹中工稳 } \\
\text { 店 }\end{array}$ & RC造／精 & 無 & 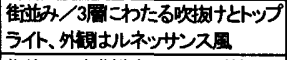 \\
\hline 日本銀行広醖支店 & 昭和11年 & \begin{tabular}{|l|}
$\begin{array}{l}\text { 長野宇平 } \\
\text { 治 }\end{array}$ \\
\end{tabular} & $\begin{array}{l}\text { RC造/3擆·地 } \\
\text { 下1階 } \\
\end{array}$ & イオニア式 & 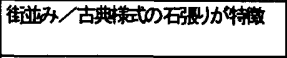 \\
\hline 広盘肪金支局 & 昭和12年 & |山田守 & $\begin{array}{l}\text { RC造/4階·地 } \\
\text { 下1階 }\end{array}$ & 無 & 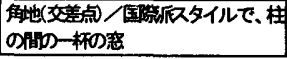 \\
\hline
\end{tabular}

\section{5. 結び}

以上により、戦前広島における建築家活動の形態とその特徴につ いて考察を試みた。

その結果：1）広島におらりる近代建築は、明治初期の軍用建物が レンガ造で建てられたのに引き続き、金融関係建物や産業建物にお いてレンガ造が建設され、さらに大正期になると民間・公共建物に おいて鉄筋コンクリート造が続々と建てられたのである。2）これ らの近代建築の設計活動の主流を占めたのは中央から広島市へ訪れ た外来建築家であった。なお広島の民間建築家の活動は現段階では 不明であり、地方営繕組織の作品も非常に少なかったのである。こ れまで、地方都市札幌や岡山などにおいては、地元に有力な営縡組 織や建築家が在籍し、旺盛な設計活動を行ったことが明らかになっ ているっこれらに比べて、広島は中国地方の中核都市でありながら、 
地元建築家や営絴組織の活動は殆ど目立たなかったのである。これ らは広島における建築家活動の一つの実像であり、そのような状況 を生み出した要因の一つとして、軍都という都市の性格が指摘でき るだろう。3）外来建築家の活動の特徴として、国の営䋨組織の建 築家と民間建築家の活動の 2 つに大別することができる。4）国の 営縓組織の建築家の活動として莪信省の山田守や上浪朗の活動が比 較的に明らかになっており、彼らは一早くヨーロッパの機能主義・ 合理主義を広島に紹介する役割を果たしたのである。このように遍 信省の建築家達は中央だけでなく、地方においても近代建築の合理 化をリードする立場であった。5）民間建築家の活動として、嘱託 による活動と建築主の依頼などによる単発的な設計活動が見られる が、まず嘱託制度による佐藤功一や増田清の活動については拙稿に おいて既に論じている。ここで注目されるのは、明治末期から大正 を経て昭和初期にかけて広島において多くの銀行建築が建てられ、 その設計には、日本を代表する建築家辰野金吾、西村好時、長野宇 平治、渡辺節、竹腰健造、山田守なども関わり、様々なデザインが 展開されたことである。近代広岛の金融建築は、規模の差はあれ、 ほぼ同一機能を有すると思われる建物が異なる建築家によって、そ れぞれのデザインを展開しつつ、約 40 年に渡って設計されてきたの である。銀行建築においては、機能的には大差はなく建物のプラン ニングや高さ、さらに構造形式も一定の範囲の中でのバリエーショ ンであった。従ってほとんど同じ構造体に、様々なデザインの外観 が適用されたことになる。建築家たちにとってのデザイン上の課題 は主として銀行建築のもつ象徽性とその表現にあったと考えられる。 その表現の手段として設計者は歴史主義から近代主義まで様々なデ ザインを、いわば様式として選択的に用いて来ており、その意味で は様式主義的設計手法といえよう。しかし金融建築においても、ヨ 一ロッパの近代建築運動の影響を受けつつ、全般的な流れとしては 近代主義的方向へと導かれたことが指摘できる。

謝辞 本研究は、2005 年度広島国際大学特別研究助成を受けた。記して謝意を表寸る。

写真の出典 写真 1 は広島市公文書館所蔵。写真 $2 、$ 写真 8 は広島県立文書館所藏。写真 は広島市公文書館所藏。写真 4 は千代田生命藏。写真 5 は『建築世界』(大正 14 年 7 月号) 所收。写真 6 は清水建設広島支店所蔵。写真 7 は『渡辺節作品集』所収。写真 9 は広島市公 文書館所蔵。写真 10 は広島公文書館所。写真 11 は中国郵政局所藏。

注

1)「広島に対する原子爆弾の効果第 1 巻物的損害調査部」(広島文化センター、昭和 57 年刊 行)。合衆国戦略爆椠調査団は、報告畵 (The United States Strategic Bombing Survey “The Effects of the Atomic Bomb on Hiroshima. Japan”) のはしがきによれば、「ローズベル 卜大統領の命令によって、1944 年 11 月 3 日に陸軍长官によって創設された」とあり、当初 は「ドイツに対する空㜪の勃果を公証かつ專門的に調查すること」を目的として創設したの である。日本に対しては、対日戦に抏ける空中攻俥のあらゆる型の効果」を明らかにすへ しというトルーマン大統領の命令によって、終戦直後から大々的に進められ、本調查団員は 民間人 300 、将校 350 、軍属 500 という規模であった。この調查団は、日本国内の戦災都市 を調查したが、特に広島については 1945 年 10 月 14 日から 11 月 26 日にかけて詳細な調査 を実施した。その結果は、1947 年 5 月に報告書としてまとめられており、本稿では被爆当 時存在した建物を確認するために、そのうちの物的調査部の文献を参照する。

2)被爆 50 周年未来への記録一七ロシマの被爆建物俚語る』(被爆建造物調查研究会編、広島 平和記念资料館発行 1996 年) 队『広島の被爆建造物/被爆 45 周年調查報告書』(被爆建造物 を考える会編、朝日新聞広島支局発行、1990年 12 月 1 日）など。

3）佐藤重夫「広島原爆ドームとヤン・レツル」日本建築学会大会学術講演便概集(中国) 昭和 43 年

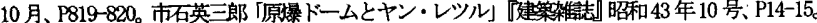
藤田文子[原爆ドームの設計者ヤン・レッルほ『新建築]、昭和 44 年 2 月号P237、同三月号P253。 4)拙稿として「建築家増田清の経歴と広島における建築活動について」日本建築学会計画系 論文集第 525 号P327 334。広島逓信診療所の建笨について」日本建築学会計画系論文集 第 540 号 p307 314。 「赤十字社広島病院と広島における建築家佐藤功一の活動に開する考 察、日本建築学会計画系論文集、第 551 号 $\mathrm{p} 335-341$ 。などがある。

5)研究方法としては、一定の公刊された文献に建物名や建築家名 (建築組織を含む) が掦載

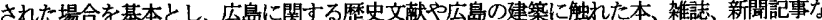
どにより、必要な情報を整えることになる。本研究で指寸近代建築は、いくつかの木造建筑 を除いて非木造建筑に限定している。梏建物を除外したのは、被爆で残存したものは少な く、現時点では木造も含めて全て把握するのは困難だからであり、将来条件を限定して把握
するという課題としておきたい。なお、建物名は建設時の名称に統一させる。 6)李明、その他「歴史的建物の建築寿命とその存続形態に関する考察/広島における被爆建 物の実態とその動向に着目して」（日本建築学会計画系論文集第 584 号 $\mathrm{p} 108$ ) の【表 1】に おいて調査対象であった建物のリストをまとめているので、それを参照すること。 7)例之ば鴻池銀行広島支店を子供百貨店とし、小田政倉庫を太陽劇場と間違えているなど。 8)例之は陸軍糧秼支廠、広島気象台、頼山陽文徳殿、陸軍兵器補給廠などが脱落している。 9)『広島県の歴史』(後藤陽一著、山川出版社昭和 47 年 2 月 10 日）206 頁による。

10）広島に於ける仮議事堂に於いて」（『建築雑誌』明治 28 年 11 月）による。

11）『官報』(第三千百十二号 明治 28 年 11 月 11 日) による。

12）『ひろしま歴史の焦点 下』(中国新聞社 1976 年 12 月 1 日) 58 頁による。

13）「水道の通水を祝賀して」(『目で見る広島市の 100 年』郷土出版社 1997 年 7 月所藏 には明治 31 年 8 月 25 日付 (広島市水道局提供) の完成祝賀時の写真が揭载されている。 14)写真は広島市公文畫館所藏『被爆 50 周年末来への記録一七ロシマの被爆建物は語る』 (被爆建造物調查研究会編、広島平和記念资料館発行 1996 年) 198 頁に揭载されている。 15）軍事施設の整備は大正期、世界的な軍縮の流九の中で、一時停滞するが、昭和初期には、 軍事体制強化の中で扗充の時代を迎える。

16）『被爆 50 周年末来への記録一七ロシマの被爆建物は語る』(被爆建造物調査研究会編、 広島平和記念资料館発行 1996 年) 122 頁による。

17) 新修広鳥市史』(第 4 巻・文化風俗史編、第 $6 ， 7$ 巻・资料編広島市役所 $1958 、 59 、 60$

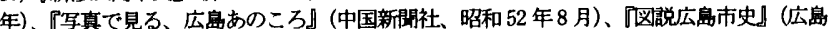
市公文覀館 1989 年)、『広島新史 歴史編』(広岛市、昭和 59)、『ひろしま歴史の焦点下』

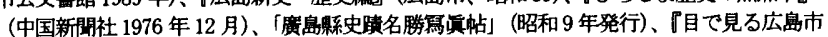

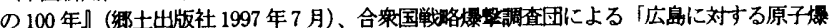

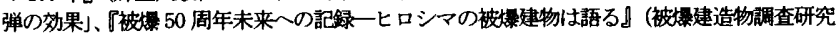
会編、広岛平和記念资料剆発行 1996 年) などを参考にした。

18)前渭注 17 の料に『日本の建朋治大正昭和 1 10 巻』（材松貞次郎企画・編集 三省堂 1979

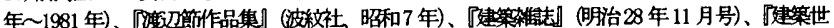
界』(大正 3 年 7 月号、大正 14 年 7 月号、昭和 11 年 2 月号)、国際建密』(昭和 11 年 2 月号)『日 本建穼士』(昭和 4 年 7 月号)、『建築と社会』(昭和 5 年11月号) 等を加えて考にした。

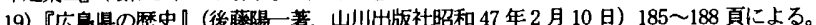
20)昭和 4 年 3 月 20 日から 5 月 13 日までの 55 日間、広岛市では昭和産業博筧会が閉催され る。『真で見る、広岛あのころ』(中国新閉社、昭和 52 年 8 月) 90〜91 頁には博筧会第 1 会場やモンゴル館の風景が截っている。なお、86 頁〜89 頁には帝人広岛工場、錦華人粗、 東洋工業、年詰工場、広岛三菱造船所などが揭载されている。

21）前掲注 17 の资料に、『日本の建築明治大正昭和 1 10 卷』（村松貞次郎企画・編集、三 省堂 1979 年 1981 年)、『进謟の建築』(常盤書房 1933 年)、『山田守建築作品集』(東海 大学、昭和 42 年)、『福屏五十年史』(福屋社史編集委貣会編 1980 年 4 月)、『広禹富國馆 新筑落成記念』（合资会社清水組、昭和 11 年 8 月 22 日）等を加えて参考にした。

22)『目で見る広島市の 100 年』(鄉土出版社 1997 年 7 月) 23 頁に広岛瓦斯広岛工場、33 頁 には帝国人組広島工場と広岛電気軌道火力発花所の写真と説明文が揭载されている。

23）『広島市の文化財第 43 集広岛市近世近代建築物調查報告』(広岛市教育委員会 1989 年) 58 頁を参照

24）『福屋五十年史』(福屋社史編集委員会編 1980 年 4 月）による。

25）『広盘富國館新築落成郡念』（合资会社清水組、昭和 11 年 8 月 22 日）には、広島富國館 工事概要が詳しく揭载されている。

26)学株小太郎（1870１953）は、イギリスて建案を学んだ後、明治29年10月16 日海里技師とし

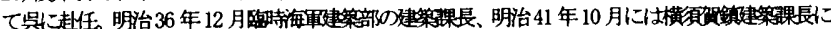

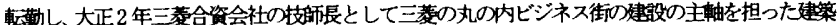

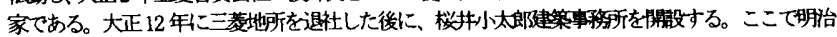

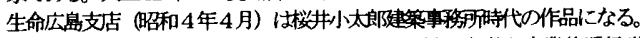

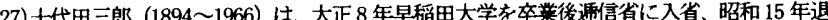
官し、早稲田大学で教鞭をとったとされ、長野㛝下にその作品が多いとされている。 28)「広島遇信診療所の建築について」日本建築学会計画系論文集第 540 号 $\mathrm{p} 307$ 。 29) 增田清（明治 21 年〜昭和 52 年）住、大正 2 年 7 月に東京帝国大学工学部建案学科を卒 業し、主に大阪を拠点として建築活動を行い、鉄筋コンクリート構造などの学術分野におい ても幅広くその才能を発揮した人物である。

30)増田清については、拙稿「建築家増田清の経歴と広島における建築活動について」（日本 建学会計画系論文集第 525 号P327〜334）を参照すること。次に、佐藤功一については批 稿「赤十字社広島病院之広島における建築家佐藤功一の活動に関する考察」(日本建築学会 計画系論文集、第 551 号 P335-341）を参照すること。

31) 辰野金吾の人物像については、藤森照信「かたちの精華/辰野式」(『日本の建筑明治大 正昭和 3 /国家のデザイン』三省堂昭和 54 年 2 月 20 日）を参照すること。

32) 日本銀行広島出張所と三十四銀行広島支店の作品は、「国家のデザイン」（『日本の建築 明治大正昭和』三省堂に所収）171 ペーシ浱野金吾年譜の作品リストに載っている。 33)西村好時の業績については伊藤三千雄十前野暁「様式美の挽歌」（『日本の建築明治大正 昭和 8 』省堂昭和 57 年 8 月 10 日）を参照すること

34)宗兵蔵の業績については、坂本勝比古「商都のデザイン」（『日本の建築明治大正昭和 5 』 三省堂昭和 55 年 9 月 10 日）を参照すること。

35)長野宇平治の人物像については、藤森照信「国家のデザイン」(『日本の建築明治大正昭 和 3 』省堂昭和 54 年 2 月 20 日) を参照すること。

36)『建築世界』大正 14 年 7 月号口絵に「三井銀行広島支店新筑設計図」が揭載され、設計 は「工学博士長野宇平治事務所」となっている。

37)渡辺節の業績については、山口廣「都市の精華/関西の建築界」(『日本の建築明治大正 昭和 6 』省堂昭和 54 年 9 月 1 日）を参照すること。

38)『創業百年史』(広島銀行編 1979 年) 211 頁「芸備銀行設立の経緯」による。

39）『創業百年史』(広島銀行編 1979 年） 276 頁「本店新築」による。

40) 『侴業百年史』（広島銀行編 1979 年）276 頁「本店新築」による。

41)竹腰健造の業績については、坂本勝比古「商都のデザイン」(『日本の建築明治大正昭和 5 上省堂昭和 55 年 9 月 10 日）を参照すること。

42) 池上重康, 越野 武, 角 幸博佻海道帝国大学の営䋨組織の沿革と建築技術者につ て」(日本建築学会計画系論文集第 541 号)、角 幸博「田上義也の初期作品について」(日本 建筑学会大会学術梗概集、1985)、前同「貄築家マックス・ヒンデルの経歴と作品について」 （日本建築学全計画系論文集第 465 号P175～181）、上田恭嗣「建築家薬師寺主計の経歴と 建築活動について」（日本建築学会計画系論文集第 509 号 P209〜215）などによる。 